\title{
THE EFFECT OF TERIPARATIDE THERAPY ON REGULATORS OF BONE TURNOVER AND QUALEFFO-41
}

\author{
TERIPAARATID TEDAVISINININ KEMIK DÖNGÜSÜ DÜZENLEYICILERİ VE \\ QUALEFFO-41 ÜZERINE ETKISII
}

\author{
Ece HARMAN \\ Korhan Barış BAYRAM \\ Gökçen KOCABAŞ ÜNAL \\ Serkan AKÇAY \\ Serpil BAL \\ Hüseyin CAN \\ Hasan Kamil SUCU
}

\section{SUMMARY}

Aim: The aim of this cross-sectional study was to compare the effects of teriparatide therapy on anabolic hormones and bone turnover markers and quality of life in patients with osteoporotic fractures.

Material and method: Patients with severe osteoporosis defined as lumbar total T-score or femur neck T-score $\leq-4.0$ and at least 2 lumbar vertebral compression fractures were enrolled. 15 patients were on teriparatide therapy and 15 patiens had no therapy. ALP, osteocalcin, GH, IGF-1, IGFBP and SHBG levels were determined. QUALEFFO-41 was used for QOL evaluation.

Findings: In the teriparatide group ALP and osteocalcin levels were significantly higher $(\mathrm{p}<0.05)$. GH, IGF-1, IGFBP and SHBG levels did not differ significantly $(\mathrm{P}>0.05)$. In teriparatide patients, physical function $(\mathrm{a}, \mathrm{b}, \mathrm{c}, \mathrm{d}, \mathrm{e})$, general health evaluation (f) and total QUALEFFO-41 scores were significantly lower, while mental function (g) scores were significantly higher $(p<0.05)$. Physical function scores $b$ and $\mathrm{c}$ were negatively correlated with IGF-1 $(\mathrm{p}<0.05)$. Treatment duration in teriparatide group was negatively correlated with physical function scores a, b, c, d and general health score (f) $(\mathrm{p}<0.05)$.

Conclusion: In this study teriparatide therapy was shown to raise the levels of bone turnover markers significantly and affect quality of life positively in osteoporotic patients with vertebral fractures and these improvements were correlated with treatment duration.

Key words: Growth Hormone, Osteoporosis, Quality of life,Spinal Fractures, Teriparatide

\footnotetext{
Department of Endocrinology and Metabolism (Spec. Dr. E. Harman)

Department of Physical Therapy and Rehabilitation (Assoc. Prof. Dr. S. Bal, Spec.Dr. K. B. Bayram)

Department of Orthopaedics and Traumatology (Spec. Dr. S .Akçay)

Department of Family Medicine (Assist. Prof. Dr. H. Can)

Department of Neurosurgery (Assoc. Prof. Dr. H. K. Sucu)

İzmir Katip Çelebi University Ataturk Training and Research Hospital, İzmir-TURKEY

Ege University Medical Faculty, Deparment of Endocrinology and Metabolism, İzmir (Spec. Dr. G. Kocabaş Ünal)

Corresponding Author: Ece Harman, MD
} 


\section{ÖZET}

Amaç: Osteoporotik vertebral kırık nedeniyle teriparatid tedavisi alanlarda kemik döngüsü düzenleyicileri ile yaşam kalitesi ölçütlerinin incelenmesi.

Gereç ve Yöntem: Çalışmaya kemik mineral yoğunluğu ölçüm değerlerine göre ileri osteoporotik (toplam lomber omurga veya femur bölgesi T skoru $\leq-4.0$ ) ve en az iki vertebrada kompresyon fraktürü olan olgular (Grup $\mathrm{B}, \mathrm{s}=15$, teriparatid alan / Grup A, s=15, tedavi almayan) alındı. Serum ALP, osteokalsin, BH, IBF-1, IBFBP-3 ve SHBG değerlendirildi. Yaşam kalitesi özel bir anket olan QUALEFFO-41 ile değerlendirildi.

Bulgular: Tedavi grubunda alkalen fosfataz ve osteokalsin değerleri kontrol grubuna göre anlamlı yüksekti $(\mathrm{p}<0,05)$. $\mathrm{BH}$, IBF-1, IBFBP-3 ve SHBG açısından gruplar arasında anlamlı fark yoktu ( $p>0,05)$. Tedavi alan grupta fiziksel işlev $(a, b, c, d, e)$, genel sağlık değerlendirmesi (f) ve toplam QUALEFFO puanları düşük $(p<0,05)$; zihinsel işlev (g) değerlendirme puanı ise yüksek bulundu $(p<0,05)$. Tedavi alan grupda yaşam kalite dizininde yeralan fiziksel işlev " $b$ " ve "c" skorları ile "IBF-1" arasındaki ilişki olumsuz idi $(\mathrm{p}<0,05)$. Tedavi edilen olguların yaşam kalite dizin skorları ile tedavi süresi incelendiğinde; fiziksel işlev skoru "a,b,c,d" ve genel sağlı skoru "f" ile tedavi süresi arasında olumsuz ilişki saptandı $(\mathrm{p}<0,05)$.

Sonuç: Osteoporotik vertebral kırıklı olgularda teriparatid tedavisinin kemik formasyon belirteçlerinde artış sağladığı, yaşam kalitesini olumlu yönde etkilediği ve bu durumun tedavi süresiyle ilişkili olduğu saptanmıştır.

Anahtar Sözcükler: Büyüme Hormonu, Osteoporoz, Spinal kırıklar, Teriparatid,Yaşam kalitesi

\section{INTRODUCTION}

Growth hormone $(\mathrm{GH})$ and insulin-like growth factor1 (IGF-1) are involved in lifelong process of regulating the balance between bone formation and resorption. While GH and IGF-1 affect prepubertal longitudinal bone growth, skeletal maturation and act to increase bone mass, in adults they play a role in maintaining existing bone mass by creating an anabolic effect on trabecular and cortical bones. With advancing age, reductions in growth hormone levels, physical performance and bone mineral density and an increase in body fat mass are observed in line with decreased growth hormone releasing hormone and increased somatostatin secretion. Systemic IGF-1 is synthesized primarily in the liver, depending on the growth hormone levels. Insulin-like growth factor binding proteins (IGFBPs) are involved in maintaining levels of freely circulating IGF-1 at $1 \%$ or less of the total amount. IGFBP-3 is the major component of circulating IGF complex and inhibits the action of IGF-1. GH also contributes to secretion of parathyroid hormone (PTH) by regulating activities of renal $1 \alpha$-hydroxylase and 24-hydroxylase enzymes, conferring an indirect action on bone metabolism (1). PTH raises IGF-1 levels and helps cell proliferation. A significant correlation between bone mineral density and IGF-1 levels was shown in GH-deficient individuals and IGFBP-3 levels were found to be a prominent marker for IGFBP-3 in healthy individuals $(2,3,4)$.

Sex hormone binding globulin (SHBG) is a plasma glycoprotein which regulates bioavailability of sex steroids including $5 \alpha$-dihydrotestosterone, testosterone and $17 \beta$-estradiol by binding these sex hormones with great affinity and SHBG was suggested as an indicator of cortical bone macroarchitecture (5). Osteocalcin is a bone-specific protein that is synthesized by noncollagenous osteoblasts found in the bone matrix. It is a marker for high bone turnover rate and reduced bone mineral density in correlation with histomorphometric structure of the bone. Similar to serum osteocalcin levels, serum alkaline phosphatase (ALP) activity is another useful diagnostic parameter which indicates bone formation and resorption.

In patients with severe osteoporosis whose response to anti-resorptive therapy is inadequate, new bone formation might be achieved by stimulating osteoblastic activation using a PTH analogue (teriparatide 1-34 rh PTH). PTH may exert its anabolic activity by regulating growth factors, IGF-1 and structures such as sclerostin, via an indirect action. However, the exact molecular mechanisms responsible for these activities have not yet been fully elucidated (6). In studies, it was shown that back pain subsided during teriparatide therapy and this improvement was maintained after discontiunation of medical therapy (7).

In this study, a cross-sectional assessment was planned in order to examine sociodemographic data (retrospectively) of patients who were receiving teriparatide treatment for an osteoporotic vertebral fracture and patients not on any treatment, to evaluate both study groups with respect to parameters including GH, IGF-1, IGFBP-3, SHBG, osteocalcin and ALP and to investigate effects of therapy and its duration on these parameters and quality of life. 


\section{MATERIALS AND METHODS}

\section{Sample Selection}

The study enrolled female patients with established diagnosis of osteoporotic vertebral fracture who admitted to outpatient clinics of Department of Physical Therapy and Rehabilitation and Department of Endocrinology and Metabolism Disorders and did not receive any treatment for osteoporosis (Group A, n=15) and other female patients who were started on teriparatide therapy (Group B, n=15). Enrolled patients were fully informed about the purpose and method of the study and gave written informed consent. The study was approved by the local ethics committee. Subjects who had any thyroid, parathyroid, hepatic or renal disorders, inflammatory joint disease, history of malignancy, history of using medications known to affect bone metabolism and history of traumatic vertebral farctures were excluded from the study.

\section{Bone Mineral Density Measurement}

BMD measurements from lumbar spine and hip region of the dominant extremity (proximal femur) were obtained by using a DEXA instrument (Norland XR36, Norland Medical Systems Inc., Fort Atkinson, USA). Patients were positioned as instructed by the manufacturer with the aid of supplied accessories. Severely osteoporotic patients (total lumbar spine or total femur T-score $\leq-4.0$ ) as evidenced by bone mineral density (BMD) results and those patients with at least two vertebral compression fractures were enrolled. A vertebral fracture was defined as $25 \%$ or less reduction in any measurements of anterior, medial and posterior height of the vertebra compared to adjacent one, as determined by lateral radiographies of thoracic and lumbar region.

Laboratory Measurements: Serum GH, IGF-1, IGFBP, PTH, SHBG and Osteocalcin levels were obtained by an Immulite 2000 autoanalyzer (Siemens Healthcare Diagnostics, Deerfield, IL, USA) using chemiluminescent method and commercial kits.

\section{Questionnaire}

A questionnaire for sociodemographic data (Appendix 1) was generated which included age, education level, body weight, height, menarche age, parturition number, pregnancy and lactation periods, age and duration of menopause, history of comorbid conditions, sedentary life style, family history of fractures, medication use, coffee, alcohol or smoking habits, dietary habits, consumption of calcium-rich food and amount ingested (milk, yogurt, cheese, fish, red meat). Also,
Quality of Life Questionnaire of the European Foundation for Osteoporosis (QUALEFFO-41) was administered (Appendix 2) (8). QUALEFFO-41 was used in the evaluation of quality of life, which is a specific questionnaire. This questionnaire contains a total of 41 questions under 7 subsections of pain, daily living activities, household chores, mobility (these three are found under "physical functions" heading), social activity, general health evaluation and mental function. Score for each subscale was found by adding scores from questions of subscales and converting the sum into a 0-100 point scale. Total QUALEFFO-41 was obtained by adding scores from all questions and converting the sum into a $0-100$ point scale (9). In this scale, 0 point indicates "best" and 100 points indicates "worst" condition for each subscale and total.

Data Analysis: Statistical analysis of data was performed using SPSS 15.0 for Windows software package with 95\% confidence. Chi-Square and Fisher's Exact tests were used for within-group comparisons of categorical variables and Mann Whitney U test for between-group comparisons of continous variables. Pearson and Spearman correlation statistics was used for analysis of correlation between variables. A $p$ value below 0.05 was considered significant.

\section{FINDINGS}

Mean age of patients treated by teriparatide for osteoporotic verebral fractures (Group B) was 78,8 $\pm 4,25$ (years) and mean age of non-treated patients (Group A) was 76,47 $\pm 5,33$ (years). Age, body weight, height, duration of menopause, parturition number, lactation period, diteary habits (smoking, alcohol, coffee consumption, calcium intake), life style (active/sedentary) were similar in both groups.

Comparison of both groups with respect to laboratory parameters revealed statistically significantly higher ALP and osteocalcin values in the treatment group versus non-treated group $(\mathrm{p}<0,05)$. GH, IGF-1, IGF-BP and SHBG values did not differ statistically significantly in both groups $(p>0,05)$. Breakdown of laboratory parameters by patient groups is given in Table 1 .

For the evaluation of quality of life, scores for pain, daily living activities, household chores, mobility, social activities, general health evaluation and total QUALEFFO score were statistically significantly lower in the treatment group compared to non-treated group $(\mathrm{p}<0,05)$, whereas mental function evaluation score was statistically significantly higher in the treatment group $(\mathrm{p}<0,05)$ compared to non-treated group. 
Table 1. Breakdown of bone turnover regulators by patient groups.

\begin{tabular}{|l|l|l|l|l|}
\hline & $\begin{array}{l}\text { Group A } \\
(\mathbf{n = 1 5})\end{array}$ & $\begin{array}{l}\text { Group B } \\
(\mathbf{n = 1 5})\end{array}$ & $\begin{array}{l}\text { Total } \\
(\mathbf{n = 3 0})\end{array}$ & $\boldsymbol{p}$ value \\
\hline ALP & $70.13 \pm 49.80$ & $85.80 \pm 35.47$ & $77.97 \pm 43.22$ & 0.016 \\
\hline Osteocalcin & $2.16 \pm 0.47$ & $4.33 \pm 2.30$ & $3.25 \pm 1.97$ & 0.001 \\
\hline GH & $1.23 \pm 1.14$ & $1.99 \pm 2.14$ & $1.61 \pm 1.73$ & $>0.05$ \\
\hline IGF-1 & $108.95 \pm 55.38$ & $115.75 \pm 62.18$ & $112.35 \pm 57.96$ & $>0.05$ \\
\hline IGFBP-3 & $17.63 \pm 27.73$ & $36.73 \pm 109.95$ & $27.18 \pm 79.38$ & $>0.05$ \\
\hline SHBG & $72.57 \pm 37.77$ & $68.75 \pm 27.70$ & $70.66 \pm 32.6$ & $>0.05$ \\
\hline
\end{tabular}

Assessment of laboratory values and parameters for quality of life index showed a negative correlation between scores of daily living activities and household chores in the quality of life questionnaire and "IGF-1" among treated patients $(\mathrm{p}<0,05)$.

When the association between scores for quality of life index and duration of therapy was examined by the treatment group, negative correlations were found between duration of therapy and scores for pain, daily living activities, household chores, mobility, general health evaluation $(p<0,05)$. There was not any correlation between laboratory parameters among treated patients.

\section{DISCUSSION}

Growth hormone and IGF-1 play an important role in the bone metabolism and lead to increased bone fragility and osteoporosis risk in parallel with suppression of GH/IGF-1 axis with advancing age (10). IGF-1 has a potent stimulatory effect on proliferation of osteoblasts and synthesis of bone-specific proteins in cell culture $(11,12)$. Bone mineral density was decreased compared to normal subjects and circulating IGF-1 levels correlated with bone mineral density in GH-deficient individuals (2,3). IGFBP-3 is the major component of circulating IGF complex and inhibits the action of IGF-1. In one study, decreased levels of IGFBP-3 were found among patients with osteporosis compared to healthy subjects but GH and IGF-1 levels were similar in both groups (13). In another study; IGFBP-3 levels were found to contribute to variations in bone mineral density among healthy subjecs and IGF-1 and IGFBP-3 were significantly lower in osteoporotic patients compared to healthy individuals (14).
ALP and osteocalcin are important markers of bone resorption and formation. Osteocalcin is a product of osteoblasts. Studies have shown significantly higher ALP and osteocalcin levels among osteoporotic women compared to non-osteoporotic women (15). This increase was apparent within the first 5 years after the onset of menopause and represents increased bone turnover.

SHBG has a key role in bone loss. It is the main predictor of vertebral and peripheral (particularly proximal femur) bone fractures. An inverse correlation was shown between bone mineral density and SHBG levels among males and females. A weak association was found between SHBG levels and markers of bone turnover (5). IGF-1 levels were reported to show a strong negative correlation with SHBG (16). SHBG showed a moderate correlation with the markers of bone resorption and a weak correlation with markers of bone formation (particularly osteocalcin) (17).

Teriparatide (1-34 rhPTH), a PTH analogue, is an anabolic agent which helps formation of new bone tissue via a stimulatory effect on osteoblasts. PTH inhibits apoptosis of osteoblasts and increases IGF-1 synthesis independent of GH. IGF-1 has strong anabolic effects on the bones (18). IGF-1 levels were shown not to increase following 24-hour PTH infusion but significant increases were seen in IGFBP-3 levels among healthy female subjects (19). Moreover, in studies, C-terminal of PTH was reported to increase apoptosis of osteocytes and stimulate ALP and other markers of osteoblastic activity (20). At least $75 \%$ increase in bone levels of ALP and osteocalcin was reported after completion of teriparatide therapy (21). Also, there are results showing improvements in parameters of quality of life, relief of pain symptoms 
and elimination of emotional disorders and fear of fall (22). One study reported that fracture risk and back pain diminished during 18 months of teriparatide therapy and these improvements were sustained after discontinuation of therapy (7).

In this study, we found significantly increased serum osteocalcin and ALP levels among treated patients. When results were analyzed according to duration of treatment (0-6 months / 6-12 months / 12-18 months), significantly low scores for pain and general health evaluation in the quality of life questionnaire and significantly decreased SHBG levels were observed in patients treated for a period of 12 to 18 months. This was considered to result from anabolic action of teriparatide therapy. Ultimately, accelerated bone formation and fracture improvement lead to diminished pain and positive effects on general health. Specifically, impaired posture after a fracture results in advancement of pain to chronic state and disruption of phsyical, social and mental functions. In their study, Panico et al. (23) demonstrated significant improvements in all parameters of the quality of life indexQUALEFFO scale with teriparatide therapy due to increased levels of ALP (a marker of bone turnover) and mainly in pain. In a study conducted by Maugeri et al. (24), the efficacy of teriparatide therapy was investigated among osteoporotic subjects with severe fractures and significant improvements were observed particulary at the end of 18 months in all parameters of the quality of life index- QUALEFFO scale, which were maintained up to 24 months. Manuele et al. (25) stated that teriparatide therapy is an effective therapeutic option for osteoporotic patients with severe fractures who are refractory to other treatments and showed positive effects mainly on pain and physical function and all other indicators of quality of life.

As an extension to our study, regulators of bone turnover and contribution of these markers to prognosis may be evaluated also in patients treated with antiresorptive agents. With increased life expectancy and greater number of cases seen among geriatric patients with osteoporotic vertebral fractures, there is a need to consider treatment cost as well as treatment efficacy in the therapeutic decision making.

Abbreviations: ALP (Serum alkaline phosphatase), GH (Growth Hormone), IGF-1 (Insulin-like growth factor-1), IGFBP (Insulin-like growth factor binding protein), BMD (Bone mineral density), PTH (Parathyroid hormone), SHBG (Sex hormone binding globulin), QUALEFFO-41 (Quality of life questionnaire of the European Foundation for Osteoporosis).

\section{REFERENCES}

1. Wei S, Tanaka H, Kubo T, Ono T, Kanzaki S, Seino Y. Growth hormone increases serum 1,25-dihydroxyvitamin D levels and decreases 24,25-dihydroxyvitamin D levels in children with growth hormone deficiency. Eur J Endocrinol. 1997 Jan;136(1):45-51. PMID:9037126.

2. Johansson AG, Burman P, Westermark K, Ljunghall S. The bone mineral density in acquired growth hormone deficiency correlates with circulating levels of insulin-like growth factor I. J Intern Med. 1992 Nov;232(5):447-52. PMID:1453131.

3. Holmes SJ, Economou G, Whitehouse RW, Adams JE, Shalet SM. Reduced bone mineral density in patients with adult onset growth hormone deficiency. J Clin Endocrinol Metab. 1994 Mar;78(3):669-74. PMID:8126140.

4. Johansson AG, Forslund A, Hambraeus L, Blum WF, Ljunghall S. Growth hormone-dependent insulin-like growth factor binding protein is a major determinant of bone mineral density in healthy men. J Bone Miner Res. 1994 Jun;9(6):915-21. PMID: 7521562

5. Hoppé E, Bouvard B, Royer M, Audran M, Legrand E. Sex hormone-binding globulin in osteoporosis. Joint Bone Spine. 2010 Jul;77(4):306-12. PMID: 20452803

6. Misiorowski W. [Parathyroid hormone and its analogues molecular mechanisms of action and efficacy of osteoporosis therapy]. Endokrynol Pol. 2011;62 Suppl 2:32-6. Polish. PMID:22125020.

7. Fahrleitner-Pammer A, Langdahl BL, Marin F, Jakob F, Karras D, Barrett A,Ljunggren Ö, et al. Fracture rate and back pain during and after discontinuation of teriparatide: 36-month data from the European Forsteo Observational Study (EFOS). Osteoporos Int. 2011 Oct;22(10):2709-19.

8. Lips P, Cooper C, Agnusdei D, Caulin F, Egger P, Johnell O,. etal.Quality of life in patients with vertebral fractures: validation of the Quality of Life Questionnaire of the European Foundation for Osteoporosis (QUALEFFO). Working Party for Quality of Life of the European Foundation for Osteoporosis. Osteoporos Int. 1999;10(2):150-60.

9. Koçyigit H, Gülseren S, Erol A, Hizli N, Memis A. The reliability and validity of the Turkish version of Quality of Life Questionnaire of the European Foundation for Osteoporosis (QUALEFFO).Clin Rheumatol 2003 Feb; 22(1): 18-23. PMID: 12605312

10. Agnusdei D, Gentilella R. GH and IGF-I as therapeutic agents for osteoporosis. J Endocrinol Invest. 2005;28(8 Suppl):32-6. Review. PubMed PMID: 16323827.

11. Hock JM, Centrella M, Canalis E. Insulin-like growth factor I has independent effects on bone matrix formation and cell replication. Endocrinology. 1988 Jan;122(1):254-60. PMID: 3335207.

12. Schmid C. The regulation of osteoblast function by hormones and cytokines with special reference to insulin-like growth factors and their binding proteins. J Intern Med. 1993 Dec;234(6):535-42. PMID:7505030.

13. Johansson AG, Eriksen EF, Lindh E, Langdahl B, Blum WF, Lindahl A, et al.Reduced serum levels of the growth hormonedependent insulin-like growth factor binding protein and a negative bone balance at the level of individual remodeling units in idiopathic osteoporosis in men. J Clin Endocrinol Metab. 1997 Sep;82(9):2795-8. 
14. Wüster C, Blum WF, Schlemilch S, Ranke MB, Ziegler R. Decreased serum levels of insulin-like growth factors and IGF binding protein 3 in osteoporosis. J Intern Med. 1993 Sep;234(3):249-55. PMID:7689089.

15. Atalay S, Elci A, Kayadibi H, Onder CB, Aka N. Diagnostic utility of osteocalcin, undercarboxylated osteocalcin, and alkaline phosphatase for osteoporosis in premenopausal and postmenopausal women. Ann Lab Med. 2012 Jan;32(1):23-30. Epub 2011 Dec 20. PubMed PMID: 22259775; PubMed Central PMCID:PMC3255495.

16. Gomez JM, Maravall FJ, Gomez N, Navarro MA, Soler J. Determinants of sex hormone-binding globulin concentrations in a cross-sectional study of healthy men randomly selected. J Nutr Health Aging. 2007 Jan-Feb;11(1):60-4. PubMed PMID:17315082.

17. Chapurlat RD, Bauer DC, Cummings SR. Association between endogenous hormones and sex hormone-binding globulin and bone turnover in older women: study of osteoporotic fractures. Bone. 2001 Oct;29(4):381-7. PMID: 11595622.

18. Dempster DW, Cosman F, Parisien M, Shen V, Lindsay R. Anabolic actions of parathyroid hormone on bone. Endocr Rev. 1993 Dec;14(6):690-709. Review. Erratum in: Endocr Rev 1994 Apr;15(2):261. PubMed PMID: 8119233.

19. Johansson AG, Baylink DJ, af Ekenstam E, Lindh E, Mohan $\mathrm{S}$, et al.Circulating levels of insulin-like growth factor-I and II, and IGF-binding protein-3 in inflammation and after parathyroid hormone infusion. Bone Miner. 1994 Jan;24(1):25-31 PMID: 7514466
20. Divieti $\mathrm{P}$, Inomata $\mathrm{N}$, Chapin $\mathrm{K}$, Singh $\mathrm{R}$, Jüppner $\mathrm{H}$, Bringhurst FR. Receptors for the carboxyl-terminal region of pth(1-84) are highly expressed in osteocytic cells. Endocrinology. 2001 Feb;142(2):916-25. PMID: 11159865.

21. Glover SJ, Eastell R, McCloskey EV, Rogers A, Garnero P, Lowery J, et al.Rapid and robust response of biochemical markers of bone formation to teriparatide therapy. Bone. 2009 Dec;45(6):1053-8. Epub 2009 Aug 11. PMID: 19679211.

22. Lau AN, Ali SH, Sawka AM, Thabane L, Papaioannou A, Gafni A, Adachi JD. Improvement in health-related quality of life in osteoporosis patients treated with teriparatide. BMC Musculoskelet Disord. 2008 Nov 7;9:151. PMID: 18990249.

23. Panico A, Lupoli GA, Marciello F, Lupoli R, Cacciapuoti M, Martinelli A, et al.Teriparatide vs. alendronate as a treatment for osteoporosis: changes in biochemical markers of bone turnover, BMD and quality of life. Med Sci Monit. 2011 Aug;17(8):CR442-448. PMID: 21804463.

24. Maugeri D, Russo E, Luca S, Leotta C, Mamazza G, Sorace R,et al.. Changes of the quality-of-life under the treatment of severe senile osteoporosis with teriparatide. Arch Gerontol Geriatr. 2009 Jul-Aug; 49(1): 35-8. Epub 2008 Jun 13. PMID: 18555544 .

25. Manuele S, Sorbello L, Puglisi N, Grasso S, La Malfa L, D'Urbino G, et al.. The teriparatide in the treatment of severe senile osteoporosis. Arch Gerontol Geriatr. 2007; 44 Suppl 1: 249-58. PMID: 17317460. 


\section{Appendix 1:}

\section{OSTEOPOROSIS EVALUATION FORM:}

Date:

Phone:

Name/Family Name:

Gender: F M

Age:

Education level:

Body weight: Height: BMI:

Menarche age: $\quad$ Number of parturition:

Pregnancy period: Lactation period:

Age and duration of menopause:..............

Hysterectomy or Overectomy:

Comorbid Illnesses:

Inactive - Sedentary life: No Yes

Family history for fractures: : No Yes

Chronic use of medications and durations of therapies:

Alcohol: $\quad$ Smoking: $\quad$ Coffee:

Calcium Intake: Milk (1glass/day):

Yogurt (1 cup/day):

Cheese (1slice/day):

Fish (1 serving/week):

Other: red meat: 


\section{Appendix-2}

\section{QUALEFFO-41 Quality of life questionnaire}

\section{A- PAIN}

The five questions in this section regard your situation in the last week.

1) How often have you had back pain in the last week?
A) none
B) 1 day per week or less
C) 2-3 days per week
D) 4-6 days per week
E) every day

2) If you have had back pain, for how long did your back pain last during daytime?
$\begin{array}{llll}\text { A) none B) 1-2 hours } & \text { C) 3-5 hours }\end{array}$
D) 6-10 hours
E) all day

3) How severe is your back pain at its worst?
A) no back pain B) mild
C) moderate D) se- vere E) unbearable

4) How is your back pain at other times?
A) no back pain B) mild
C) moderate
D) severe
E) unbearable

5) Has the back pain disturbed your sleep in the last week?
A) less than once per week
B) once a week
C) twice a week
D) every other night
E) every night

\section{B- PHYSICAL FUNCTIONS: ACTIVITIES OF} DAILY LIVING

The next 4 questions regard your situation at present.

6) Do you have problems with dressing?
A) no difficulty
B) a little difficulty
C) moderate difficulty
D) may need some help
E) impossible without help

7) Do you have problems when bathing or taking a shower?
A) no difficulty
B) a little difficulty
C) moderate difficulty
D) may need some help
E) impossible without help

8) Do you have problems with getting to or using the toilet?
A) no difficulty
B) a little difficulty
C) moderate difficulty
D) may need some help
E) impossible without help

9) How well do you sleep?
A) sleep undisturbed
B) wake up sometimes
C) wake up often
D) sometimes I lie awake for hours
E) sometimes I have a sleepless night

\section{C-PHYSICAL FUNCTIONS: HOUSEHOLD CHORES}

The next 5 questions are concerned with the present situation. If someone else performs these tasks in your house, please answer as though you were responsible for them.

10) Can you do the cleaning?
A) without difficulty
B) with a little difficulty
C) with moderate difficulty
D) with great difficulty
E) impossible

11) Can you prepare meals?
A) without difficulty
B) with a little difficulty
C) with moderate difficulty
D) with great difficulty
E) impossible 
12) Can you wash the dishes?
A) without difficulty
B) with a little difficulty
C) with moderate difficulty
D) with great difficulty
E) impossible

13) Can you do your day to day shopping?
A) without difficulty
B) with a little difficulty
C) with moderate difficulty
D) with great difficulty
E) impossible

14) Can you lift a heavy object weighing about $9 \mathrm{~kg}$ (eg., a case of milk bottles or a one-year old child) and carry for at least 9 meters?
A) without difficulty
B) with a little difficulty
C) with moderate difficulty
D) with great difficulty
E) impossible

\section{D- PHYSICAL FUNCTIONS: MOBILITY}

\section{The next 8 questions regard your present situation.}

15) Can you get up from a chair?
A) without difficulty
B) with a little difficulty
C) with moderate difficulty
D) with great difficulty
E) only with help

16) Can you lean forward?
A) easily
B) fairly easily
C) moderately
D) very little
E) impossible

17) Can you kneel down?
A) easily
B) fairly easily
C) moderately
D) very little
E) impossible

18) Can you climb upstairs to the next floor of a house?
A) without difficulty
B) with a little difficulty
C) with at least one rest
D) only with help
E) impossible

19) Can you walk 90 meters?
A) fast without stopping
B) slowly without stopping
C) slowly with at least one stop
D) only with help
E) impossible

20) How often have you been outside in the last week?
A) every day
B) 5-6 days per week
C) 3-4 days per week
D) 1-2 days per week
E) less than once a week

21) Can you use public transportation?
A) without difficulty
B) with a little difficulty
C) with moderate difficulty
D) with great difficulty
E) only with help

22) Have you been affected by the changes to your figure due to osteoporosis (for example, loss of height, increase in waist circumference, shape of your back)?
A) not at all
B) a little
C) moderately
D) quite a bit
E) very much

\section{E- SOCIAL ACTIVITIES}

23) Do you do any support currently?
A) yes
B) yes but with some restrictions
C) not at all

24) Can you do your gardening?
A) yes
B) yes but with some restrictions
C) not at all
D) I do not have a garden

25) Do you have any hobbies currently?
A) yes
B) yes but with some restrictions
C) not at all

26) Can you go to places like a cinema or theater?
A) yes
B) yes but with some restrictions
C) not at all
D) no cinema or theater within my neighbourhood 
27) How often did you visit your friends or relatives during the last 3 months?
A) once a week or more
B) once or twice a month
C) less than once a month
D) none

28) How often did you participate in social activities (clubs, social gatherings, religious activities, charity) during the last 3 months?
A) once a week or more
B) once or twice a month
C) less than once a month
D) never

29) Does your back pain or disability interfere with your intimacy (including sexual activity)?
A) not at all
B) a little
C) moderately
D) severely
E) not applicable

\section{F- GENERAL HEALTH EVALUATION}

30) For your age, in general, would you say your health is ...
A) excellent
B) good
C) satisfactory
D) fair
E) poor

31) How would you rate your overall quality of life during the last week?
A) excellent
B) good
C) satisfactory
D) fair
E) poor

32) How would you rate your overall quality of life compared with 10 years ago?
A) much better now
B) slightly better now
C) unchanged
D) slightly worse now
E) much worse now

\section{G-MENTAL FUNCTIONS}

Think of your condition during the last week when answering the next 9 months.

33) Do you tend to feel tired?
A) in the morning
B) in the afternoon
C) only in the evening
D) after strenuous activity
E) almost never

34) Do you feel downhearted?
A) almost every day
B) 3-5 days a week
C) 1-2 days a week
D) once in a while
E) almost never

35) Do you feel lonely?
A) almost every day
B) 3-5 days a week
C) 1-2 days a week
D) once in a while
E) almost never

36) Do you feel full of energy?
A) almost every day
B) 3-5 days a week
C) 1-2 days a week
D) once in a while
E) almost never

37) Are you hopeful about your future?
A) never
B) rarely
C) sometimes
D) quite often
E) always

38) Do you get upset over little matters?
A) never
B) rarely
C) sometimes
D) quite often
E) always

39) Do you find it easy to make contact with people?
A) never
B) rarely
C) sometimes
D) quite often
E) always 
40) Are you in good spirits most of the day?
A) never
B) rarely
C) sometimes
D) quite often
E) always

41) Are you afraid of becoming totally dependent?
A) never
B) rarely
C) sometimes
D) quite often
E) always

\section{COMMUNICATION:}

Ece HARMAN, MD

Email: ecarmu@gmail.com

Mobile phone: +90 5372545328

Izmir Ataturk Training and Research Hospital,

Department of Endocrinology, Izmir, Turkey 